\title{
Flipped Classroom for Improving Self-Regulated Learning of Pre-Service Teachers
}

\author{
https://doi.org/10.3991/ijim.v14i09.11858 \\ Cecep Kustandi $\left({ }^{\bowtie}\right)$, Hirmana Wargahadibrata \\ Universitas Negeri Jakarta, Jakarta, Indonesia \\ cecep_kustandi@unj.ac.id \\ Dini Nur Fadhillah \\ Universitas Sebelas Maret, Solo, Indonesia \\ Suprayekti, Kunto Imbar Nursetyo \\ Universitas Negeri Jakarta, Jakarta, Indonesia
}

\begin{abstract}
This study aims to describe the use of the flipped classroom for improving the self-regulated learning of pre-service teachers. This explanatory mixed-method collected the information related to the characteristics of students who take Theory Learning courses through e-learning. This research collaborated with students of 2018 which included 30 students and 7 lecturers of Theory Learning courses from 7 study programs at the Faculty of Education Science, Universitas Negeri Jakarta. The results show by a one-tailed test at a significant level 0,05 with $n-1=29$ is 2,045 , so tcount $(5,843)>$ ttable $(2,045)$, means an increase after the use of flipped classroom learning outcomes in Learning Theory courses. And also improving self-regulated students. It can be concluded that in general the learning independence of the students of the Faculty of Education Science of Universitas Negeri Jakarta in the indicators has self-confidence categorized as positive.
\end{abstract}

Keywords_-Flipped classroom, blended learning, e-learning, self-regulated

\section{Introduction}

In the digital era, we often found the widespread use of electronic devices in almost every human activity[1]. As well as presentations in the learning process, lectures using the LCD projector. The utilization of e-learning for learning media has a function to complement and or improve the quality of learning and helps in improving student understanding[2]. The emergence of more advanced technology and influence on learning methods which include the formulation of organizing teaching materials, strategies and management of activities by taking into account the objectives, constraints, and characteristics of students so that effective, efficient, and attractive learning outcomes are obtained[3]. That is an educational innovation. Also, a multimedia-based e-learning system in which there is an attractive graphical display will make students more 
interested in following the learning process [4]. Since 1970, e-learning began to be introduced and developed rapidly in 1990 [5]. The utilization of e-learning has many advantages, especially its use in the field of education. Horton explained that the use of information technology and computer technology can be useful for creating learning experiences [6]. The use of IT is designed in a way that is formulated, organized, and made according to the learning needs of both the instructor and the needs of students to create effective learning experiences. On the other hand, Arkorful and Abaidoo explained that online learning not only provides convenience in accessing learning wherever and whenever, but also provides opportunities for students to become more active, and learn according to their abilities and learning styles [7]. Thus, the benefits offered are more towards the nature of saving travel costs and the flexibility of implementing learning. Besides, it integrates classroom teaching with online experience and combines a variety of media to strengthen interaction and direct contact with students in the classroom, which provides meaningful and motivating learning [8]. In Malaysia, the Ministry of Higher Education has urged every university to introduce blended learning as elearning in their teaching and learning process as a new approach [9]. Whereas in Indonesia the government has not required Blended Learning as an approach. Therefore, there are still less-skilled students who are hesitant, less motivated, and face difficulties in associating learning with technology applications [10]. Under flipped classroom according to Bergmann and Sams is learning that is usually done in the class conducted by students at home, and questions that are usually used as homework discussed and worked on in class[11]. The reverse class approach, although used for years in humanities and basic sciences, is increasingly increasing popularity in the education field [12]. Some recent reviews focus on the use of flipped classrooms in professional health education which shows that flipped classrooms can have a positive impact on student learning outcomes and student satisfaction and give instructors more opportunities to get involved [13]. This was also shown by Galway and Cameron in their study entitled online learning flipping in public health graduate education [14]. The results of the study showed an increase in the achievement of learning outcomes obtained. Online learning also can be used by mobile devices [15]. To realize online learning-based education, teachers must be given the provision of computational thinking because many teachers do not learn about computers in their early education[16]. That is why the authors conducted an analysis of the development of flipped classrooms in prospective teachers at Universitas Negeri Jakarta, Indonesia. Meanwhile to improve the quality of the learning process they use e-learning with a learning management system through Moodle [17]. This method can also be applied to pre-service teachers as a basis for mastering to use e-learning.

In this research, the authors interested in concern on the flipped classroom. It is an approach student-centered activity that increases activity in the learning process compared to traditional classroom approaches [18]. Interestingly, the increase in e-learning models such as mobile educational applications makes parents and educators need to understand this [19]. Students who will become teachers are certainly required to understand and be able to use mobile education applications. This requires an understanding of the flipped classroom pre-service teacher before teaching in the classroom. As we know, during formal teaching time, instructors facilitate student-driven discussion 
of material through case scenarios, allowing for complex problems, solving, peer interaction, and in-depth understanding of concepts It can be said that inverted classes have existed in the broader field of education for several years, until the requirements of students must complete previous assignments in preparation for attending classes to discuss concepts at a deeper level [20]. Based on the elaboration of problem identification, the researcher conducts a problem limitation to focus the research only on the second item contained in the identification of the problem that has been previously described. As for more details, namely studying the development studies or steps that have been carried out in developing lectures through HyLearn web portal to see whether the course created have been able to be used effectively and efficiently for lectures and student who become an educator.

\subsection{Self-regulated learning}

Flipped classroom tries to review the material previously instructed by the lecture and replace it with what was previously done at home. The assigned activity is now taking place in the classroom [21]. A preliminary study conducted in 2017 for 67 students in Primary School Teacher Education Program, Universitas Negeri Jakarta, Indonesia, explained that students used smartphones more to access Instagram and interact with other social media [22]. This shows that there is a need to direct the use of smartphones into the learning process. So, they are not focused solely on social media. According to Zheng, the involvement stimulated by the flipped classroom pedagogy inherently satisfies students[23]. So that pre-service teachers can understand that technological progress requires that they can use e-learning in the learning process. And pre-service teachers also need to know the existing e-learning models.

The authors have previously conducted research related to VR Use in Online Learning for Higher Education at Universitas Negeri Jakarta[24]. The results showed that students were motivated in the learning process. In improving student understanding related to online learning, it is not just the use of VR but also the use of the flipped classroom for improving self-regulated learning [25]. As we know, lecturers cannot supervise and direct students for 24 hours straight. Thus, self-regulated learning is beneficial for students to learn. Self-regulated learning skills are also very important to mediate success in different learning contexts [26]. The concept of independent learning is becoming increasingly relevant in the study of learning and academic achievement, especially in higher education, where quite typical demands are placed on students[27]. Students who will become a teacher need understanding and must study independently. In this era, pre-service teachers need to know about online learning through the game[28]. So, this time they can do independent learning includes thoughts, feelings, and planned and adapted actions that are all managed by students to achieve learning goals. Actions, the environment and the people who are connected with these actions and the environment affect each other[29]. Self-regulated learning also able to make students proactive in managing their learning activities [30]. Because students who will become an educator need a good learning program. One of the programs is self-regulated learning in students is reflected in their self-control in dealing with problems that occur in the learning process. In other words, students learn as controllers of 
their learning activities. Students monitor and motivate themselves throughout the learning process. Also, students are expected to be able to evaluate and monitor their learning outcomes following the expected targets in the learning process[31]. During the learning process, students are expected to be able and actively find relevant learning resources by utilizing information technology. This is under the effort to make students independent in learning. Adequate information technology facilities and infrastructure enable students to easily access a variety of learning resources. However, the number of learning resources is not necessarily comparable to student learning outcomes. For this reason, researchers conducted research related to flipped classrooms for improving the self-regulated learning of pre-service teachers.

This research-based on Flaherty and Philips show flipped classrooms improved academic performance and student and staff to building learning in under-graduate education and post-graduate education[32]. This shows that cooperation between lecturers and students is needed in using e-learning through flipped classrooms. Students must understand how to use flipped classrooms in activities that are normally carried out in class and outside the classroom. The conventional lecture-based approach that is most commonly applied in higher education, the reverse class approach requires students to engage with material independently at their own pace and then actively apply and engage with course content and with each other during face-to-face sessions[33]. In this study, the flipped classroom is the first provided by uploading the material on a website (on a blog or social media like Facebook and YouTube) in the form of learning videos that must be downloaded or accessed online and studied by students at home or outside the classroom. Thus, the use of smartphones on students does not just make a status on social media. With learning session in class is used for group discussions and work on assignments. In its implementation in Indonesia, flipped classroom can only be applied in schools where students already have adequate facilities and infrastructure considering that this strategy requires students to watch video tutorials at home. There are several studies relating to the implementation of flipped classroom on learning as conducted by Basal entitled the implementation of a flipped classroom in foreign language teaching shows students who are taking advanced reading and writing courses at a public university in Istanbul, Turkey as the subject of his research[34]. Besides, the English teacher has a positive perception of the use of inverted classes as an integral part of face-to-face courses. It could have been concluded that flipping a class is beneficial in terms of 4 categories based on content analysis of responses: learning at one's own pace, advancing student preparation, overcoming class time limitations, increasing participation in class.

When the results of previous studies explain the increase in learning for students and have a positive impact on lecturers, Marlowe through his psychology research provides an explanation that flipped classrooms make students enjoy the associated benefits of being able to choose their assignments and explore concepts they found interesting more in-depth[34]. The use of a flipped classroom is used as an opportunity to engage millennial students through active learning strategies and conclude that to introduce new strategies transferred from teacher and student thinking, teachers must research with alternative strategies in the classroom[35]. As instructors who will use new strategies, this is very important in the world of education which is reflected in effective 
learning. Technology-based on e-learning does not only focus on students and teachers, but on the use of the internet, technologies that are useful in producing learning resources and media for students, methods of delivering messages, and organizing courses in an organized group. In e-learning, the teacher's role shifts to become a tutor who has the task of supervising and guiding students during online learning. Unfortunately, no research discusses the flipped classroom for improving self-regulated learning of pre-service teachers.

In connection with the future competency needs of teachers in the face of the millennial generation, it is important to increase teacher knowledge in using the flipped classroom approach[36]. On the other hand, as a lecturer must also provide understanding to students who will become teachers related to the use of flipped classrooms that can improve self-regulated[37]. Self-regulated learning is a combination of academic learning skills and self-control that makes learning easier, so students are more motivated[38]. Actually, through this research, the authors want to see how online learning facilities from the Faculty of Education at Universitas Negeri Jakarta in instilling flipped classrooms for students who will become teachers. Therefore, along with the development of information and communication technology, these faculty aim to become a leading education in Indonesia. Students used e-learning portals have been provided in every study program. Last year, an e-learning portal belonging to the Faculty of Education Science was developed, which aims to facilitate online or hybrid learning for students. Not only that the level of student activity in conducting learning through the HyLearn (http://fip.unj.ac.id/hylearn) Faculty of Education e-learning portal is also still low. But it is not yet known which aspects are the main issue of the low use of HyLearn by students and lecturers. Therefore, this research aim how is progress students use of flipped classroom in enhancing self-regulated learning of pre-service teachers at the Faculty of Education Science at Universitas Negeri Jakarta

\section{Method}

The general objective of this research is to survey the development studies conducted by each lecturer in each study program at the Faculty of Education Science at Universitas Negeri Jakarta related to learning through online courses by the HyLearn web learning portal. Then, describe how the progress of students related to the implementation of the flipped classroom to improve self-regulated. Self-regulated learning is a combination of abilities and desires. Self-regulated learning can take place if students systematically direct their behavior and logic by paying attention to instructions, assignments, carrying out processes and interpreting knowledge, repeating information to remember it and developing and maintaining positive beliefs about learning abilities and abilities anticipating learning outcomes[39]. Therefore, the authors used explanatory sequential mixed method design to conducted the data[40]. Researchers collect data and analyze quantitative data then collect and analyze qualitative data[41]. 


\subsection{Research design}

This study conducted data from the population at the Faculty of Education Science, Universitas Negeri Jakarta. For the first step, the researchers determined the research subjects of 625 student's year 2018 and 145 lecturers with the following information:

Table 1. Numbers of Students and Lecturers

\begin{tabular}{|c|l|c|c|}
\hline No & \multicolumn{1}{|c|}{ Study Program } & Students & Lecturers \\
\hline 1 & Counseling and Guidance & 90 & 15 \\
\hline 2 & Special Education & 90 & 23 \\
\hline 3 & Community Education & 85 & 15 \\
\hline 4 & Educational Technology & 90 & 15 \\
\hline 5 & The Education of Elementary School Teacher & 85 & 35 \\
\hline 6 & The Education of Early Childhood Teacher & 92 & 20 \\
\hline 7 & Educational Management & 93 & 22 \\
\hline Total & 625 & 145 \\
\hline
\end{tabular}

Source: private document (2019)

And based on the entire online course that has been registered on the HyLearn website there are about 64 online courses including 2 online courses for basic education courses. While the sample is part or representative of the population studied. This study uses purposive sampling which means that the selection of samples is based on special characteristics[42]. This is because researchers want to get the right sample following the desired criteria. The lecturer criteria are as follows: Has developed courses that can become online courses on the HyLearn website, the online course is not only listed but there is already material or content that will be provided and also active in using HyLearn for study purposes. For the student, criteria are required to be in the third year and use online courses in the learning process and also took the Learning Theory course. Then actively use HyLearn FIP. The 625 students who entered the criteria, two methods were carried out, namely answering the questionnaire and adjusting the criteria. Data collection is done by distributing instruments to student respondents who are used as research subjects. The questionnaire was created using Google Forms to enable respondents to answer the questionnaire without the need to meet face to face. From the results of the questionnaire, the researchers chose 7 lecturers and 30 students who represented each study program Faculty of Education Science, Universitas Negeri Jakarta. After conducting purposive sampling, the researcher developed a learning strategy in collaboration with 7 lecturers for the selection of delivery systems, sorting and grouping the series of materials, describing the learning components included in learning, determining how to group students during learning, building the Learning structure to convey learning[43]. Then, students were divided into 7 groups of 2-3 people each to be given guidance related to learning strategies. Hereafter, to fill out the questionnaire, students first log in and use HyLearn as a learning media for flipped classrooms. Online courses can be utilized by students by accessing the site http://fip.unj.ac.id/hylearn/. After accessing the site, the following are details of using the product:

Log in: On the HyLearn home page, students are directed to log in first by entering their username and password. If the student does not have an account, click on the ' 
register ' link to create a new account. When registering a pop-up window will appear and fill in according to student data, then click register.

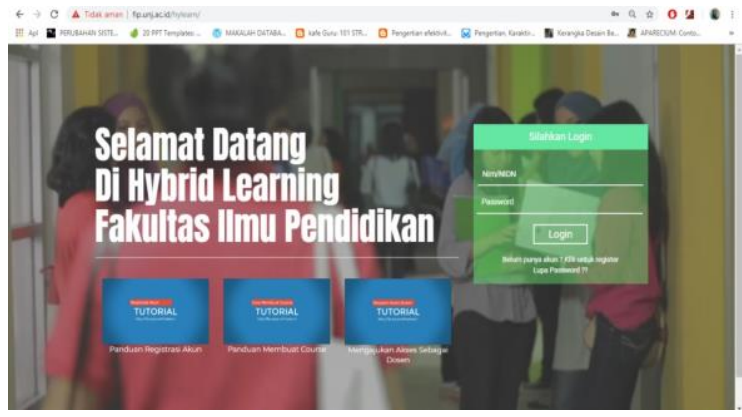

Fig. 1. Homepage Hylearn

Enroll course: After successfully logging in, students will be directed to the HyLearn home page. To be able to take the Theory of Learning and Learning courses, students can click on ' All courses ...' on the My Courses tab. Then select the 'TP' category. Then select and click Learning Theory and Learning. The Enrollment key can be filled in by entering the enrollment password. After entering the Learning Theory course students can see the instruction page first.

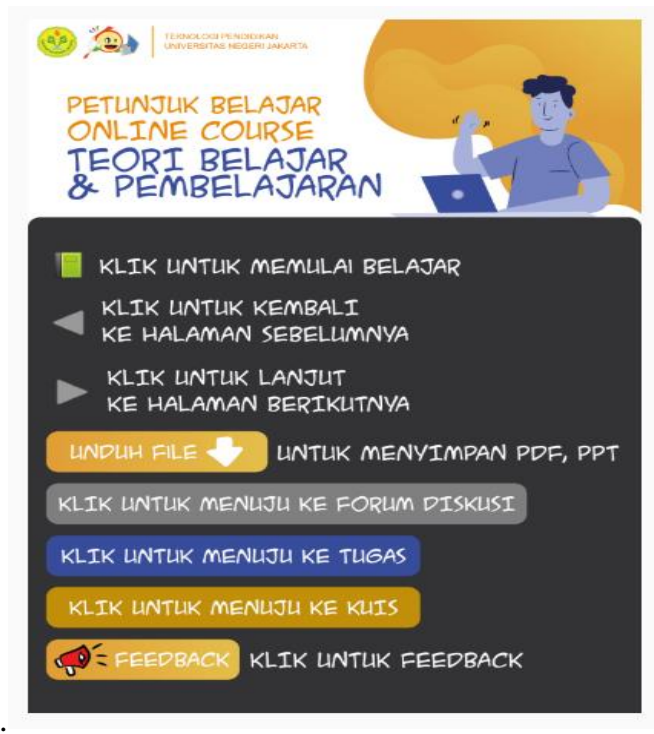

Fig. 2. Display TBP Online Course Instructions 


\subsection{Learning activities in the online course}

After joining the Learning Theory course, students can access learning materials, take part in discussion forums, do quizzes, and other activities available on the online course.

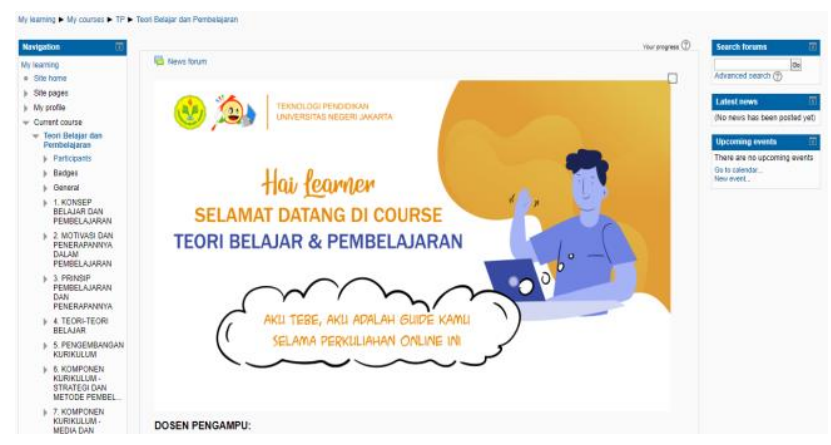

Fig. 3. Display Page Introduction to Learning Theory course

What will be seen after the instructions is an introductory page for learning and learning theory? In the initial appearance, there is an opening greeting "Hi Learner! I was your guide during online learning". On the left side, there is a navigation profile of each student's account, participants, and seven materials related to the Learning Theory course. When a student clicks on the subject matter, a book, assignment, forum, quiz, and feedback icon will come out. So, students can see the contents of the material by the existing icon.

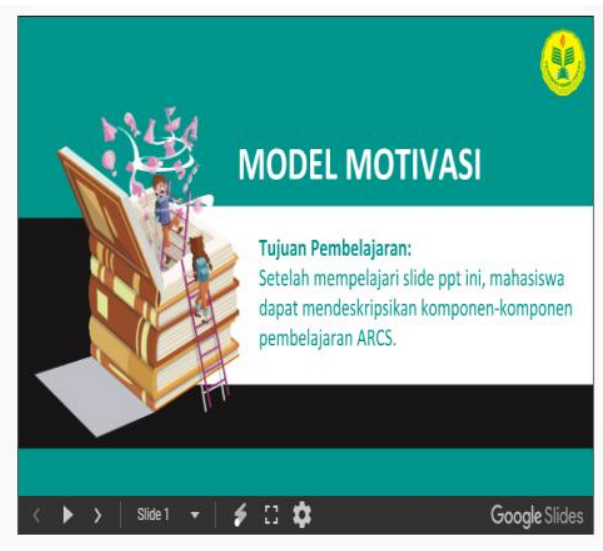

Fig. 4. Example of PowerPoint Media Display

In the above display, students who click on learning material through PowerPoint media will exit the display. 


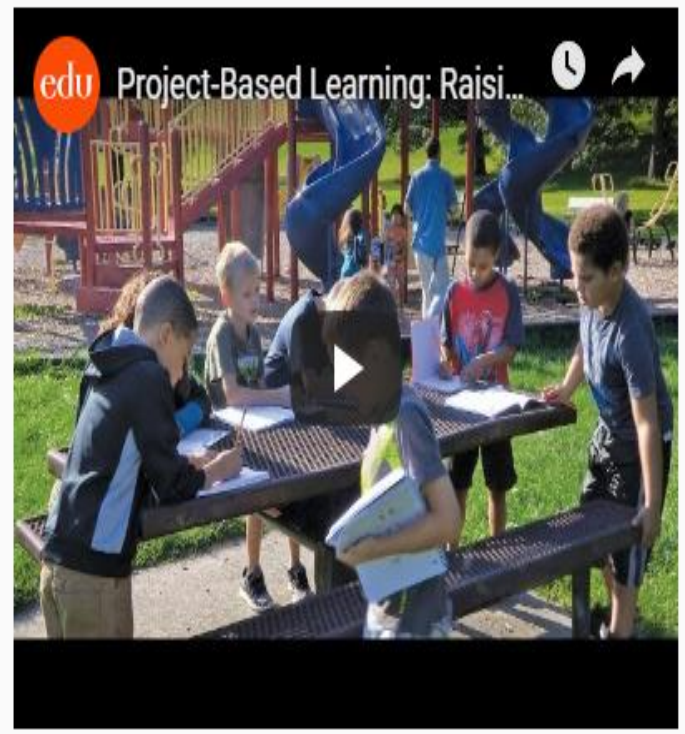

Fig. 5. Example of Video Media Display

The picture above is also a learning media innovation other than PowerPoint: video media. Students can find examples of the application of learning theory. Information collected about various activities, materials, methods, media, and technology, as well as the suitability of assessment instruments with the expected learning objectives[44]. After giving a briefing to the students, the lecturer conducts an interview to request their assessment of the quality of the learning material from their respective perspectives in 40 minutes. Data collected information through a questionnaire on 30 students who have attended the Learning Theory course. The questionnaire that was distributed contained questions that were used to obtain information in the form of learning styles and experiences of students using the online learning system used Likert Scale [45]. Four-point Likert scale with categories labeled "strongly agree", "agree", "disagree", and "strongly disagree"[46].

\section{Result and Discussion}

Moreover, the students' age range in the study was from 18 to 20. In the experimental and control groups, in the age range of 18 , there were $26.7 \%(n=8), 19$, there were $43.3 \%(n=13)$ participants, and 20 , there were $30 \%(n=9)$. Furthermore, according to the field of education major in the experimental and control groups, it shows that $10 \%$ $(n=3)$ of the students were from counseling and guidance study program $20 \%(n=6)$ were from Special Education Study Program, $10 \%(\mathrm{n}=3)$ were from community education, 20\% $(n=6)$ were from Educational Technology Study Program, 10\% $(n=3)$ were 
from The Education of Elementary School Teacher, $10 \%(n=3)$ were from The Education of Early Childhood Teacher, 20\% $(n=6)$ were from Educational Management Study Program.

\subsection{HyLearn as learning media for flipped classrooms}

In this study, the approach used is qualitative research, so researchers use descriptive statistics. From some of the calculations above, the researcher completes other descriptive statistical calculations in the form of maximum value, minimum value, mean (mean), middle value (median), values that often appear (mode) and standard deviation (standard deviation). The following is a summary table of descriptive statistics pre-test and post-test at the small group trial stage.

Table 2. Descriptive Statistic of Pre-Test and Post Test

\begin{tabular}{|l|c|c|}
\hline \multicolumn{1}{|c|}{ Descriptive Statistic } & Pre-Test Result & Post-Test Result \\
\hline Minimum & 27,5 & 27,5 \\
\hline Maximum & 75 & 75 \\
\hline Mean & 42,75 & 56 \\
\hline Median & 45 & 57,5 \\
\hline Mode & 45 & 50 \\
\hline Standard Deviation & 9,15 & 10,46 \\
\hline
\end{tabular}

source: private document (2019)

The following is presented a descriptive statistical chart obtained based on table 2 above so that it can be seen the difference in the acquisition of pre-test and post-test results on student learning outcomes before and after using flipped classroom in Learning Theory course. Furthermore, the data from the pre-test and post-test results in the field test phase are presented in the form of frequency distribution tables which are used to view the distribution of data produced by respondents in the field test trials and are used in the calculation of average values (mean) and deviations standard (standard deviation).

Table 3. Frequency Distribution of Pre-Test and Post-Test Results on Students Learning Outcomes

\begin{tabular}{|c|c|c|c|c|c|c|c|c|c|}
\hline \multirow{2}{*}{ Data } & & \multicolumn{4}{|c|}{ Pre-Test } & \multicolumn{4}{c|}{ Post-Test } \\
\cline { 2 - 11 } & $\boldsymbol{X i}$ & $\boldsymbol{f i}$ & $\boldsymbol{f i x \boldsymbol { i }}$ & $\boldsymbol{( x \boldsymbol { i } - \boldsymbol { x } ) \mathbf { 2 }}$ & $\boldsymbol{f i}(\boldsymbol{X i}-\boldsymbol{X} \boldsymbol{)} \mathbf{2}$ & $\boldsymbol{f i}$ & $\boldsymbol{f i X \boldsymbol { i }}$ & $(\boldsymbol{X} \boldsymbol{i}-\boldsymbol{X}) \mathbf{2}$ & $\boldsymbol{f i}(\boldsymbol{X} \boldsymbol{i}-\boldsymbol{X})$ \\
\hline $20-29$ & 24,5 & 1 & 24,5 & 324 & 324 & 1 & 24,5 & 1024 & 1024 \\
\hline $30-39$ & 34,5 & 9 & 310,5 & 64 & 576 & 1 & 34,5 & 484 & 484 \\
\hline $40-49$ & 44,5 & 17 & 756,5 & 4 & 68 & 3 & 133,5 & 144 & 432 \\
\hline $50-59$ & 54,5 & 2 & 109 & 144 & 288 & 13 & 708,5 & 4 & 52 \\
\hline $60-69$ & 64,5 & 0 & 0 & 484 & 0 & 10 & 645 & 64 & 640 \\
\hline $70-79$ & 74,5 & 1 & 74,5 & 1024 & 1024 & 2 & 149 & 324 & 648 \\
\hline Total & & 30 & 1275 & & 2280 & 30 & 1695 & & 3280 \\
\hline
\end{tabular}

Source: Private Document (2019) 
Based on table 3 above, the results of the calculation of the average pre-test are obtained:

$$
\bar{X}=\frac{\sum f_{i} X_{i}}{\sum f_{i}}=\frac{1275}{30}=42,5
$$

while the average post-test acquisition

$$
\bar{X}=\frac{\sum f_{i} X_{i}}{\sum f_{i}}=\frac{1695}{30}=56,5
$$

and the standard deviation of the pre-test is

$$
S D=\sqrt{\frac{\sum f_{i}\left(X_{i}-\bar{X}\right)^{2}}{\sum f_{i}}}=\sqrt{\frac{2280}{30}}=9,15
$$

while the standard deviation post-test

$$
S D=\sqrt{\frac{\sum f_{i}\left(X_{i}-\bar{X}\right)^{2}}{\sum f_{i}}}=\sqrt{\frac{3280}{30}}=10,46
$$

The following are the results of the calculation of the " $\mathrm{t}$ " test

i. Looking for Mean of Difference:

$$
M_{D}=\frac{\sum D}{N}=\frac{385}{30}=12,83
$$

ii. Looking for Standard Deviation of Difference (SDD):

$$
\begin{array}{r}
S D_{D}=\sqrt{\frac{\sum D^{2}}{N}-\left(\frac{\sum D}{N}\right)^{2}}=\sqrt{\frac{9138}{30}-\left(\frac{385}{30}\right)^{2}}= \\
\sqrt{304,58-12,8333}=\sqrt{139,89}=11,827
\end{array}
$$

Looking for Error Standard from Mean of Difference that is $S E_{M D}$ by using the formula: $\quad S E_{M D}=\frac{S D_{D}}{\sqrt{N-1}}=\frac{11,827}{\sqrt{30-1}}=\frac{11,827}{5,385}=2,20$

iii. Looking "to" by using the formula:

$$
t_{o}=\frac{M_{D}}{S E_{M D}}=\frac{12,83}{2,20}=5,843
$$

iv. Looking t Table significance level 5\%

$$
t_{\text {tabel }}=(\alpha ; N-1)=(0,05 ; 30-1)=(0,05 ; 29)=2,045
$$

Based on these data obtained tcount of 5,843 ttable by one-tailed test at a significant level 0,05 with $n-1=29$ is 2,045 , so tcount $(5,843)>$ ttable $(2,045)$, means an increase after the use of flipped classroom learning outcomes in Learning Theory courses. 
To strengthen the results of the quantitative data above, the following are the results of researchers' interviews with students and lecturers related to self-regulated indicators. "What is your opinion about the HyLearn portal web?"

"In my opinion learning material in HyLearn is interesting, the contents are good and easy to understand. In PowerPoint, there is already a visualization available in the sample section." (Student 8, 2019)

"HyLearn is the best application that I used to learn. When I read each sub-topic is given an interesting header so that it attracted me in reading. Such as section in PowerPoint there has been provided a good animated or supporting image " (Student 9, 2019)

"HyLearn helped me to understand how to use the web as a learning model. Learning theory is full of words so, this portal web increased me to read and learn. The material is given to students not only in PowerPoint but Word, PDF, PowerPoint, Video." (Student 10, 2019)

The interview results above show that the online course model for flipped classroom makes students feel easy to use, clear material, good visualization and interesting. This is because the presence of multimedia technology changes the way students learn. The quality of learning is generally in the form of quality results relating to the experience of learning and learning[47]. So that students are interested in the study before lecturing. "How about your self-regulated while used flipped classroom in the home?"

"Because of this web portal easy to use, study Learning Theory can be flexible. That facilitates me in learning activities. So that I can increase my self-regulated to continue Learning Theory material" (Student 11, 2019)

"HyLearn helped me to self-regulated myself learn about Learning Theory. When I was in Junior High School for observing, we can read again the indicator and material of Learning Theory" (Student 28, 2019)

"Learning Theory courses are delivered through face-to-face learning in class with a duration of 120 minutes each meeting. Usually, the duration of time is not enough for lecturers to convey the topic of learning material that required material deepening. Therefore, when we used HyLearn FIP, students exercise their self-regulated at home." (Student 29, 2019)

"In my opinion learning using this online course increases my self-regulation. Because we can study wherever and whenever. HyLearn motivated me to learn how to improve to make learning model "(Student 15, 2019)

The interview results above show that students feel the ease with the presence of the Hylearn online course for Learning Theory. And also, they can control their self-regulated learning. Learning materials are also felt to be beneficial for students. This is in line with Bonwell and Eison's concept in Roehl, Reddy, and Shannon that teaching methods that promote active learning are "instructional activities that involve students in doing[35]. "Why HyLearn as a flipped classroom improve your self-regulated?"

"I thought because of the material presented is under the concept of learning objects. And there is a learning guide to help students use HyLearn as in a flipped classroom. The language used in the forum tools is very persuasive and the material referenced is very credible" (Lecture 1, 2019).

"Because this flipped classroom system can be used anywhere. The time spent on the test is very effective. The material is very clear. "(Lecture 2, 2019) 
"When we gave students project-based learning to observation in School, they can read the guide on HyLearn. So, they can improve self-regulated to solve the problem" (Lecture 3, 2019).

From the results of the interviews, the three lecturers showed that the HyLearn helped students to improve their self-regulated learning. Because web portal helps their activities before learning and provides convenience in implementing Learning Theory anywhere. It is in accordance with Bergmann and Sams[11] that is flipped classroom can reach students every day. Jacob and Luluk explained, there are steps of flipped classroom learning according to [48] namely:

a) Phase 0, students learn the material themselves at home using either textbooks or videos. It can be shown when student 11 explained about that. And then, before the lecture gave them the material of Learning Theory, they allow students to log in to HyLearn and read the material on the web.

b) Phase 1, learning in class can be divided into several heterogeneous groups to work on assignments related to the material. The assignments not only in groups but also in individuals and can be accessed through the HyLearn in Learning Theory course.

c) Phase 2, the teacher facilitates the discussion activities by providing feedback on questions and activity sheets.

d) Phase 3, teaching and learning activities end with a quiz to find out how far students understand the material.

The concept of Berret in showing the strengths of the flipped classroom learning model, namely:

a) Students have time to study the subject matter at home before the lecturer submits material in class so that students' independence is honed shows by student 29 .

b) Students can study the material in comfortable conditions.

c) Students get the full attention of the teacher when they have difficulty working.

d) Students can learn from various types of learning content both videos, books, and websites.

So the results of this study are in line with Chien who thinks that self-regulated learners have metacognitive attitudes, motivations, and are active in behavior in their learning processes[49]. The results of the study show that most students who take part in blended learning have positive self-confidence. Students who have positive self-confidence show they have the ability and strength that will be able to achieve his goal[38]. According to the Judge revealed that self-confidence can also be interpreted as a person's belief in all aspects of the advantages possessed by that person and that belief made him feel able to achieve various goals in his life[50]. The results of the study show that the majority of students who participated in blended learning learned behaved based on their positive initiatives. Someone who has an initiative can be said that the person can give birth to something new both in the form of ideas and works that are relatively different from what was before to solve a problem[29]. It can be concluded that in general the learning independence of the students of the Faculty of Education 
Science of Universitas Negeri Jakarta in the indicators has self-confidence categorized as positive.

\section{Conclusion}

Based on the results of the discussion on flipped classroom to improve self-regulated students of the Faculty of Education, Universitas Negeri Jakarta, obtained count of 5,843 ttable by one-tailed test at a significant level 0,05 with $n-1=29$ is 2,045 , so tcount $(5,843)>$ ttable $(2,045)$, means an increase after the use of flipped classroom learning outcomes in Learning Theory courses. namely:

1. Dependence on others as very positive

2. Having self-confidence as positive

3. Discipline behavior as positive

4. Having a sense of responsibility as very positive

5. Behaving based on their initiative as positive

6. Doing self-control as very positive

While the results of the discussion on the impact of the implementation of the flipped classroom for improving self-regulated were obtained as a result of very positive. So that it can be concluded that the tendency of self-regulated student learning, namely students proved to have a positive learning momentum. Students are not dependent on others; they tend to be more independent in everything. On the other hand, blended learning has proven to be very supportive in learning as well as the impact of blended learning on student learning independence which tends to be very positive.

\section{Acknowledgement}

"This article is supported by Research and Community Service Institute of Universitas Negeri Ja-karta, Ministry of Education and Culture with contract No. 5/KOMPUNJ/LPPM/V/2020."

\section{References}

[1] M. Kalogiannakis and S. Papadakis, "Evaluating pre-service kindergarten teachers' intention to adopt and use tablets into teaching practice for natural sciences," Int. J. Mob. Learn. Organ., vol. 13, no. 1, pp. 113-127, 2019. https://doi.org/10.1504/ijmlo.2019. $\underline{10016617}$

[2] N. S. Hanum, "Keefetifan e-learning sebagai media pembelajaran (studi evaluasi model pembelajaran e-learning SMK Telkom Sandhy Putra Purwokerto)," J. Pendidik. Vokasi, vol. 3, no. 1, pp. 90-102, 2013. https://doi.org/10.21831/jpv.v3i1.1584

[3] S. Papadakis, "Evaluating pre-service teachers' acceptance of mobile devices with regards to their age and gender: a case study in Greece," Int. J. Mob. Learn. Organ., vol. 12, no. 4, pp. 336-352, 2018. https://doi.org/10.1504/ijmlo.2018.10013372 
[4] T. Listyorini and A. Widodo, "Perancangan Mobile Learning Mata Kuliah Sistem Operasi Berbasis Android," Simetris J. Tek. Mesin, Elektro dan Ilmu Komput., vol. 3, no. 1, p. 25 , 2013. https://doi.org/10.24176/simet.v3i1.85

[5] D. Darmawan, Pengembangan E-Learning Teori dan Desain (I). Bandung: Remaja Rosdakarya, 2014.

[6] W. Horton and K. Horton, E-learning Tools and Technologies: A consumer's guide for trainers, teachers, educators, and instructional designers. 2003.

[7] V. Arkorful and N. Abaidoo, "The role of e-learning, advantages and disadvantages of its adoption in higher education," Int. J. Instr. Technol. Distance Learn., vol. 12, no. 1, pp. 2942, 2015.

[8] H. Khechine, S. Lakhal, D. Pascot, and A. Bytha, "UTAUT Model for Blended Learning: The Role of Gender and Age in the Intention to Use Webinars," Interdiscip. J. e-Skills Lifelong Learn., vol. 10, pp. 033-052, 2014. https://doi.org/10.28945/1994

[9] S. Yusoff, R. Yusoff, and N. H. Md Noh, "Blended Learning Approach for Less Proficient Students," SAGE Open, vol. 7, no. 3, pp. 1-8, 2017. https://doi.org/10.1177/21582 44017723051

[10] Z. Zainuddin, C. Muftia Keumala, S. Tinggi Ilmu Ekonomi Lhokseumawe, A. Room, and M. Wah, "Blended Learning Method Within Indonesian Higher Education Institutions," J. Pendidik. Hum., vol. 6, no. 2, pp. 69-77, 2018.

[11] J. Bergmann and A. Sams, Flip Your Classroom: Reach Every Student in Every Class Every Day. Washington DC: International Society for Technology in Education., 2012. https://doi.org/10.1177/073989131401100120

[12] K. F. Hew and C. K. Lo, "Flipped classroom improves student learning in health professions education: A meta-analysis," BMC Med. Educ., vol. 18, no. 1, pp. 1-12, 2018. https://doi.org/10.1186/s12909-018-1144-Z

[13] F. Chen, A. M. Lui, and S. M. Martinelli, "A systematic review of the effectiveness of flipped classrooms in medical education,” Med. Educ., vol. 51, no. 6, pp. 585-597, 2017. https://doi.org/10.1111/medu.13272

[14] L. P. Galway and E. Cameron, "Flipping Online Learning in Public Health Graduate Education," Pedagog. Heal. Promot., p. 237337991985902, 2019. https://doi.org/10.1177/ 2373379919859023

[15] N. Vidakis, A. K. Barianos, A. M. Trampas, S. Papadakis, M. Kalogiannakis, and K. Vassilakis, "Generating Education in-Game Data: The Case of an Ancient Theatre Serious Game," in Proceedings of the 11th International Conference on Computer Supported Education (CSEDU 2019), 2019, pp. 36-43. https://doi.org/10.5220/0007810800360043

[16] S. Papadakis and M. Kalogiannakis, "Evaluating a course for teaching introductory programming with Scratch to pre-service kindergarten teachers," Int. J. Technol. Enhanc. Learn., vol. 11, no. 3, 2019. https://doi.org/10.1504/ijtel.2019.10020447

[17] S. Papadakis, M. Kalogiannakis, E. Sifaki, and N. Vidakis, "Access Moodle Using Smart Mobile Phones. A Case Study in a Greek University," in Interactivity, Game Creation, Design, Learning, and Innovation, A. L. Brooks, E. Brooks, and N. Vidakis, Eds. Switzerland: Lecture Notes of the Institute for Computer Sciences, Social Informatics and Telecommunications Engineering, 2017, pp. 376-385. https://doi.org/10.1007/978-3-319-76908-0_36

[18] J. F. Strayer, "How learning in an inverted classroom influences cooperation, innovation and task orientation," Learn. Environ. Res., vol. 15, no. 2, pp. 171-193, 2012. https://doi.org/10.1007/s10984-012-9108-4

[19] S. Papadakis and M. Kalogiannakis, "Mobile educational applications for children: what educators and parents need to know," Int. J. Mob. Learn. Organ., vol. 11, no. 3, pp. 231246, 2017. 
[20] R. Pierce and J. Fox, "Vodcasts and active-learning exercises in a 'flipped classroom' model of a renal pharmacotherapy module," Am. J. Pharm. Educ., vol. 76, no. 10, 2012. https://doi.org/10.5688/ajpe7610196

[21] I. Lestari, A. Maksum, and C. Kustandi, "Mobile Learning Design Models for State University of Jakarta, Indonesia,” Int. J. Interact. Mob. Technol., vol. 13, no. 09, p. 152, 2019. https://doi.org/10.3991/ijim.v13i09.10987

[22] R. Fisher, Á. Perényi, and N. Birdthistle, "The positive relationship between flipped and blended learning and student engagement, performance and satisfaction," Act. Learn. High. Educ., 2018. https://doi.org/10.1177/1469787418801702

[23] L. Zheng, X. Li, and F. Chen, "Effects of a mobile self-regulated learning approach on students' learning achievements and self-regulated learning skills," Innov. Educ. Teach. Int., vol. 55, no. 6, pp. 616-624, 2018. https://doi.org/10.1080/14703297.2016.1259080

[24] C. Kustandi, D. N. Fadhillah, R. Situmorang, D. S. Prawiladilaga, and S. Hartati, "VR Use in Online Learning for Higher Education in Indonesia," Int. J. Interact. Mob. Technol., vol. 14, no. 01, p. 31, 2020. https://doi.org/10.3991/ijim.v14i01.11337

[25] T. Lehmann, I. Hahnlein, and D. Ifenthaler, "Cognitive, metacognitive and motivational perspectives on preflection in self-regulated online learning.," Comput. Human Behav., vol. 32, pp. 313-323, 2014. https://doi.org/10.1016/j.chb.2013.07.051

[26] S. Cassidy, "Self-regulated learning in higher education: Identifying key component processes," Stud. High. Educ., vol. 36, no. 8, pp. 989-1000, 2011. https://doi.org/10.1080/ $\underline{03075079.2010 .503269}$

[27] M. B. Postholm, "Self-regulated learning in teaching: Students' experiences," Teach. Teach. Theory Pract., vol. 17, no. 3, pp. 365-382, 2011. https://doi.org/10.1080/13540602. $\underline{2011.554713}$

[28] S. Papadakis, "Evaluating a game-development approach to teach introductory programming concepts in secondary education,” Int. J. Technol. Enhanc. Learn., vol. 12, no. 2, pp. 127-145, 2020. https://doi.org/10.1504/ijtel.2020.106282

[29] D. Pedrosa, J. Cravino, L. Morgado, and C. Barreira, "Self-regulated learning in higher education: Strategies adopted by computer programming students when supported by the SimProgramming approach," Producao, vol. 27, no. Specialissue, pp. 1-15, 2017. https://doi.org/10.1590/0103-6513.225516

[30] T. Michalsky and C. Schechter, "Preservice teachers' capacity to teach self-regulated learning: Integrating learning from problems and learning from successes," Teach. Teach. Educ., vol. 30, no. 1, pp. 60-73, 2013. https://doi.org/10.1016/j.tate.2012.10.009

[31] M. J. Lage, G. J. Platt, and M. Treglia, "Inverting the classroom: A gateway to creating an inclusive learning environment," J. Econ. Educ., vol. 31, no. 1, pp. 30-43, 2000. https://doi.org/10.1080/00220480009596759

[32] J. O. Flaherty and C. Phillips, "Internet and Higher Education The use of fl ipped classrooms in higher education: A scoping review is," Internet High. Educ., vol. 25, pp. 85-95, 2015. https://doi.org/10.1016/j.iheduc.2015.02.002

[33] A. Ahmet BASAL, "the Implementation of a Flipped Classroom in Foreign Language Teaching," Turkish Online J. Distance Educ., no. October, pp. 28-37, 2015.

[34] C. A. Marlowe, "the effect of the flipped classroom on student achievement and stress," Bozeman, 2012.

[35] Amy Roehl, Shweta Linga Reddy, and Gayta Jett Shannon, "The Flipped Classroom: An Opportunity to Engage Millennial Students Through Active Learning Strategies," J. Fam. Consum. Sci., vol. 105, no. 2, pp. 44-49, 2013. https://doi.org/10.14307/jfcs105.2.12 
[36] A. T. Steen-Utheim and N. Foldnes, "A qualitative investigation of student engagement in a flipped classroom," Teach. High. Educ., vol. 23, no. 3, pp. 307-324, 2018. https://doi.org/10.1080/13562517.2017.1379481

[37] P. H. Winne, "Improving measurements of self-regulated learning," Educ. Psychol., vol. 45, no. 4, pp. 267-276, 2010.

[38] P. H. Winne, "Self-regulated learning in research with gifted learners," High Abil. Stud., vol. 30, no. 1-2, pp. 277-287, 2019. https://doi.org/10.1080/13598139.2019.1622224

[39] A. Kaplan, A. Neuber, and J. K. Garner, "An identity systems perspective on high ability in self-regulated learning," High Abil. Stud., vol. 30, no. 1-2, pp. 53-78, 2019. https://doi.org/10.1080/13598139.2019.1568830

[40] J. Creswell, Research Design, Qualitative, Quantitative and Mixed Methods Approaches, Fourth. Sage Publication, 2014.

[41] N. Weller and J. Barnes, Finding Pathways Mixed Method Research for Studying Causal Mechanisms. Cambridge, MA: Cambridge University Press, 2014. https://doi.org/10. 1017/cbo9781139644501

[42] M. Havlíková, "Likert scale versus Q-table measures - a comparison of host community perceptions of a film festival," Scand. J. Hosp. Tour., vol. 16, no. 2, pp. 196-207, 2016. https://doi.org/10.1080/15022250.2015.1114901

[43] W. Dick, L. Carey, and J. O. Carey, The Systemic Design of Instruction 7 ed. New Jersey: Pearson, 2009.

[44] M. Yaumi, Prinsip-Prinsip Desain Pembelajaran. Jakarta: Kencana, 2013.

[45] C. J. Wigley, "Dispelling Three Myths about Likert Scales in Communication Trait Research,” Commun. Res. Reports, vol. 30, no. 4, pp. 366-372, 2013. https://doi.org/10. $\underline{1080 / 08824096.2013 .836937}$

[46] H. Wu and S. Leung, "Can Likert Scales be Treated as Interval Scales? - A Simulation Study,” J. Soc. Serv. Res., vol. 0, no. 0, pp. 1-6, 2017.

[47] Lopes, Ana Paula and F. Soares, "The International Journal of Perception and performance in a fl ipped Financial Mathematics classroom,” Int. J. Manag. Educ., vol. 16, no. 1, pp. 105113, 2018.

[48] M. Luluk, "Penerapan model pembelajaran flipped classroom untuk melatih kemandirian belajar siswa dalam pembelajaran matematika," Universitas Islam Negeri Sunan Ampel, 2017. https://doi.org/10.24252/mapan.2019v7n2a7

[49] C. W. Chien, "Taiwanese EFL undergraduates' self-regulated learning with and without technology,” Innov. Lang. Learn. Teach., vol. 13, no. 1, pp. 1-16, 2016.

[50] F. Varol, "Elementary school teachers and teaching with technology," TOJET Turkish Online J. Educ. Technol., vol. 12, no. 3, pp. 86-90, 2013.

\section{$7 \quad$ Authors}

Cecep Kustandi is a doctoral candidate of Educational Technology at Universitas Negeri Jakarta. He often works as an education trainer for teacher and school head office with the Ministry of Education and Culture and lectures at the undergraduate of Educational Technology at Universitas Negeri Jakarta. He is a book author and active in the published article in the journal. One of his books is Media Pembelajaran "Learning Media”. Email: cecep_kustandi@unj.ac.id

Hirmana Wargahadibrata is a lecture of Educational Technology at Universitas Negeri Jakarta. He is a member of Ikatan Sarjana Pendidikan Indonesia. He is also an 
assistant for International Relations to Vice-Rector for Planning and Cooperation Affairs Universitas Negeri Jakarta.

Dini Nur Fadhillah is a student of the master program in the Civics Education Department, Faculty of Teacher Training and Education, Universitas Sebelas Maret.

Suprayekti is a lecture of Educational Technology at Universitas Negeri Jakarta. She is also active in the technology of application in school education research.

Kunto Imbar Nursetyo is a lecture of Educational Technology at Universitas Negeri Jakarta. He interested in learning technology, E-learning, training for trainers and innovative learning research.

Article submitted 2019-10-13. Resubmitted 2020-03-25. Final acceptance 2020-03-27. Final version published as submitted by the authors. 